\title{
Nekrolog: Inkeri Anttila 1916-2013
}

\author{
Af Jr.dr. seniorprofessor Per Ole Träskman
}

Den 6 juli 2013 dog Inkeri Anttila i Helsingfors som följd av en hjärtinfarkt. Hon var 96 år gammal. Hennes död betyder att en av de centrala gestalterna inom nordisk kriminologi och straffrätt är borta. Hennes forskningsinsatser - särskilt inom kriminologi - är betydande och därtill var hon en framstående och framsynt kriminalpolitiker.

Inkeri Anttila disputerade i straffrätt vid Helsingfors universitet år 1946 med en avhandling om den kränktes samtycke som straffrihetsgrund. Mätt med dagens mått är avhandlingen kanske inte så märklig, men den är det historiskt sett, på grund av att hon var den första kvinnan i Finland som disputerade till doktor i juridik. Efter detta följde några andra straffrättsliga monografier bl.a. om våldtäkt samt andra juridiska artiklar. Med tiden övergick Inkeri Anttilas forskning allt mer mot kriminologi. En viktig lärobok med betydande användning i Norden är »Kriminologi i ett kriminalpolitiskt perspektiv«. En lärobok som hon skrev och publicerade tillsammans med Patrik Törnudd. Deras mångåriga och betydelsefulla samarbete förtjänar också annars att bli framhävt. Deras kriminalpolitiska synpunkter, med betoning av att brottsligheten aldrig kan utplånas, men minskas genom rationella åtgärder, blev centralt i flera av de nordiska länderna. Vad det handlar om enligt dem är att minska de samhälleliga kostnaderna för brott och brottskontroll och fördela dem så rättvist som möjligt mellan involverade parter, alltså samhälle, brottsling och brottsoffer. Det handlar inte om att bekämpa och bekriga brottsligheten, men att kontrollera den på ett rationellt och humant sätt.

På 1940-talet arbetade Inkeri Anttila vissa perioder som biträdande professor i straffrätt vid Helsingfors universitet, men efter det övergick hon till uppdrag inom kriminalvården. Till Helsingfors universitet återvände hon år 1961, nu som professor i straffrätt. Den anställningen behöll hon till år 1980. Hon var den första kvinnliga professorn i juridik i Finland. Delvis på grund av frustration över att hon inte fick tillräckligt gehör för sina idéer om att förstärka kriminologin vid Helsingfors universitet var hon en av initiativtagarna till det fristående Kriminologiska forskningsinstitutet, som senare ändrades till det Rättspolitiska forskningsinstitutet för att idag vara ett forskningsinstitut $i$ anknytning till Justitieministeriet. Hon var chef för forskningsinstitutet 1974-79. Senare var hon pådrivande när HEUNI (The European Institute for Crime Prevention and Control, affiliated 
with the United Nations) grundades och inledde sin verksamhet i Helsingfors i början av 1980-talet. Hon var justitieminister i Finland under några få månader 1986. Också i detta fall var hon den första kvinnan som hade denna post.

Inkeri Anttila var en mycket aktiv person inom det nordiska kriminologiska samarbetet. Hon publicerade flera artiklar i Nordisk Tidskrift for Kriminalvidenskab och vissa av dem har citerats ofta. Detta gäller t.ex. artikeln »Konservativoch radikal kriminalpolitik i Norden« som publicerades 1967. I början av 1970-talet var hon förman för Nordiska samarbetsrådet för kriminologi under sammanlagt sex år och hon verkade som rådsmedlem utöver denna tid. Hon blev hedersdoktor vid Uppsala universitet och Åbo universitet och hon hedrades med flera festskrifter, bl.a. en festnummer av denna tidskrift år 1986. Hon mottog också europeiska äresbetygelser.

Inkeri Anttila var mycket aktiv, ambitiös, intellektuellt begåvad, social och språkligt slagfärdig. Hon var också uppskattad som lärare och kollega, inbegripet ledare och äldre kollega. Vad som kan framstå som något märkligt - med beakatande av hennes pionjärskap som kvinnlig forskare och akademisk lärare - är att hon inte var någon aktiv anhängare av kvinnorfrågor eller genderrelaterad forskning. Själv klarade hon ju sig mycket väl i en mansdominerad värld. 